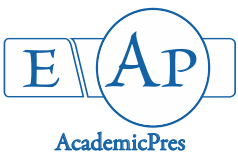

Buican Stanciu A et al. (2021)

Notulae Scientia Biologicae

Volume 13, Issue 3, Article number 11007

DOI: $10.15835 / \mathrm{nsb} 13311007$

Research Article

\title{
Spring phenology of some ornamental species, as an indicator of temperature increase in the urban climate area
}

\author{
Antonela BUICAN STANCIU ${ }^{1}$, Mariana IONESCU ${ }^{2}$, \\ Sina COSMULESCU ${ }^{3 *}$
${ }^{1}$ University of Craiova, Faculty of Horticulture, Doctoral School of Plant and Animal Resources Engineering, 13 A.I. Cuza Street, 200585, Craiova, Romania; stanciu.antonela@yahoo.com
${ }^{2}$ High School Bechet, 33 A.I. Cuza Street, 207060, Bechet, Romania; mary.yonescu@yahoo.com Romania; sinacosmulescu@hotmail.com (* ${ }^{*}$ corresponding author) \\ ${ }^{3}$ University of Craiova, Faculty of Horticulture, Department of Horticulture and Food Science, 13 A.I. Cuza Street, 200585 Craiova,
}

\begin{abstract}
The aim of this study is to provide information on the phenology of urban spring season, of some species of ornamental trees and shrubs, in the light of climate changes occurred over the recent decades. Ten species of ornamental shrubs and trees cultivated in two areas of a town located in southwestern Romania were studied. It was found that the spring season phenology of the studied species is dependent on the climatic year, in recording differences between the number of days from November 1 and the beginning of each spring phenophase, both from one species to another and from one climatic year to another, and also from one area to another; the spring phenology starting earlier in the urban area regardless of the species and the climatic year. Higher temperatures, rising from one year to another, are speeding-up the onset and development of spring phenology, regardless of species, and the urban climate through the effect of urban heat island leads to even earlier onset of spring phenophases and shortening of the growing season, so that by phenological differences existing within the species from one climatic year to another and from one climatic zone to another, spring season phenology can be considered an indicator of temperature rise.
\end{abstract}

Keywords: climate changes; rural climate; spring season phenology; temperature; urban climate

\section{Introduction}

Phenology, the time of biological reproductive events, recurring annually, provides a critical signal of climate variability and the effects of these climate changes on plants. Research conducted in recent decades has quantified the extent to which plant phenophases respond to local changes in temperature and rainfall, being specific to both location and species. The extent to which plants are affected by changes in temperature and rainfall, their ability to adapt, will ultimately determine the potential for ecological stability (Fitchett et al., 2015). Phenological observations provide an excellent mechanism to study the impact of climate changes, because climate variables are causing variations in the phenophase calendar (Zhou et al., 2016; Menzel et al. 2006; Cosmulescu and Ionescu, 2018; Cosmulescu et al., 2019, 2020). Wohlfahrt et al. (2019) found a significant advance of phenophases in areas with higher degrees of urbanization. Meng et al. (2020) stated that

Received: 23 Jun 2021. Received in revised form: 30 Aug 2021. Accepted: 03 Sep 2021. Published online: 07 Sep 2021.

From Volume 13, Issue 1, 2021, Notulae Scientia Biologicae journal uses article numbers in place of the traditional method of continuous pagination through the volume. The journal will continue to appear quarterly, as before, with four annual numbers. 
cities are ideal natural laboratories for assessing the response of plant phenology to rising temperatures. The spring phenology of plants, i.e. the beginning of seasonal cycle of plant growth, is controlled by environmental factors (e.g. temperature, rainfall and light) (Shen et al., 2016; Yang et al., 2020). Numerous studies have suggested that spring phenology occurs earlier, along with increasing temperature in regions with temperate climate (Piao et al., 2011; Buitenwerf et al., 2015; Shen and Cao, 2015). Earlier spring phenology is able to ensure a higher gross primary crop (Richardson et al., 2010), but it can also have a negative influence on ecosystem services (Keenan et al., 2014). As a result, studying the response and sensitivity of spring vegetation phenology is highly important in designing the future scenarios under the pressure of climate change and other environmental changes. Urbanization causes the change of natural environment (especially rural areas around cities) in many respects, including the microclimate (Matei et al., 2020; Tian et al., 2020). The urbanization process has the effect of increasing the local air temperature causing an urban heat island (UHI) effect, prolonging the photoperiod by introducing artificial light and turning more soil into impermeable surfaces, which eliminates rainwater infiltration and natural recharging of groundwater and the result are environmental conditions for vegetation growth, which are significantly different, between rural and urban areas, which determines the rural-urban difference of spring plant phenology (Zipper et al., 2016; Parece et al., 2018). The aim of this study is to provide information about the spring phenology of some species of ornamental trees and shrubs, in light of climate changes occurred over recent decades, under urban environmental conditions.

\section{Materials and Methods}

The research area was set-up in the town of Găești, located in the S-W of Dâmbovița County, Muntenia, Romania, at $44^{\circ} 50^{\prime}$ northern latitude, $25^{\circ} 19^{\prime}$ eastern longitude and $190.62 \mathrm{~m}$ altitude. From this area, six species of ornamental shrubs (Forsythia intermedia; Mahonia aquifolium; Spiraea vanhouttei; Syringa vulgaris; Chaenomeles japonica, Albizia julibrissin) and four ornamental trees (Aesculus hippocastanum; Prunus cerasifera; Catalpa bignonioides, Tillia tomentosa) were chosen for study, in two areas: the town center $(\mathrm{Z} 1)$ and a neighbouring area (Z2), located $5 \mathrm{~km}$ from the town center. For the analysis of the temperature factor, the climatic data recorded by the National Meteorological Institute for Găești Meteorological Station were used. Data recorded over 50 years were processed and two time periods were used for analysis and comparison: 1970-1995 and 1995-2020. The phenophases of the vegetation season, from the start of vegetation until the end of flowering, were recorded using BBCH-scale (Table 1), used by other researchers for various plant species (Stratópoulos et al., 2019; Cosmulescu and Scrieciu, 2019; Cosmulescu et al., 2020), through observations on leafing and flowering over the years 2018-2019, 2019-2020 and 2020-2021 at an interval of 2-4 days, calculating the number of days from November 1 at different phenophases.

Table 1. Description of spring phenophases recorded in ornamental species based on the BBCH code

\begin{tabular}{|c|c|c|c|}
\hline $\begin{array}{c}\text { No. of } \\
\text { phenological } \\
\text { phase }\end{array}$ & Phenological phase & $\begin{array}{c}\text { BBCH } \\
\text { Code }\end{array}$ & Description of BBCH Code \\
\hline F0 & Bud bursting & 09 & Visible green leaves \\
\hline F1 & Leaf occurrence/development & 19 & The first visible whole leaves \\
\hline \multirow{2}{*}{ F3 } & $\begin{array}{c}\text { Elongation of stem or growth of rosette, } \\
\text { development of shoots }\end{array}$ & 39 & The shoots reached 90\% of final length \\
\hline F5 & Inflorescence occurrence & 59 & Separation of floral buds \\
\hline \multirow{2}{*}{ F6 } & Flowering & 60 & The first flowers have opened \\
\cline { 2 - 4 } & Full flowering & 65 & At least 50\% of flowers are open, the first \\
\cline { 2 - 4 } & End of flowering & 69 & The end of flowering: all petals have fallen \\
\hline
\end{tabular}




\section{Results and Discussion}

\section{Regarding the analysis of temperature}

The effects of climate change on seasonal activity in terrestrial ecosystems are significant and well documented. Temperature is the main factor of many plants' development processes and, in many cases, higher temperatures have been shown to accelerate plant development and lead to the earlier transition to the next ontogenetic stage (Badeck et al., 2004). An analysis of the temperature parameter was made in Găești area, over two reference intervals (1970-1995 and 1995-2020). The variation of the average annual temperatures over the two analysed time intervals (1970-1995 and 1995-2020), of the annual average of the maximum and minimum temperatures in the analysed intervals for Găești area is presented in Table 2. The average temperature over the 1970-1995 interval is $10.15^{\circ} \mathrm{C}$, the lowest average temperature $\left(9.20^{\circ} \mathrm{C}\right)$ being recorded in 1976 , and the highest $\left(11.74^{\circ} \mathrm{C}\right)$ in 1994 . The average temperature over the period $1995-2020$ was higher, respectively 11.10 ${ }^{\circ} \mathrm{C}$ with the lowest average temperature of the range $\left(9.58^{\circ} \mathrm{C}\right)$ recorded in 1997 and the highest average temperature $\left(12.36^{\circ} \mathrm{C}\right)$ recorded in 2014 . The average annual maximum temperatures over the period 19701995 was $16.19{ }^{\circ} \mathrm{C}$ and over the period $1995-2020$ it was $17.11^{\circ} \mathrm{C}$, while the average annual minimum temperatures were $5.19^{\circ} \mathrm{C}$ over $1970-1995$ and $5.83^{\circ} \mathrm{C}$ over $1995-2020$.

Table 2. Variation of average annual temperatures over the analysed time intervals in Găești area, SouthWest Romania

\begin{tabular}{|l|c|c|c|c|c|c|}
\hline \multicolumn{1}{|c|}{$\begin{array}{c}\text { Descriptive } \\
\text { statistics }\end{array}$} & \multicolumn{2}{|c|}{ Mean temperature $\left({ }^{\circ} \mathrm{C}\right)$} & \multicolumn{2}{c|}{ Maximum temperature $\left({ }^{\circ} \mathrm{C}\right)$} & \multicolumn{3}{c|}{ Minimum temperature $\left({ }^{\circ} \mathrm{C}\right)$} \\
\hline Time interval & $1970-1995$ & $1995-2020$ & $1970-1995$ & $1995-2020$ & $1970-1995$ & $1995-2020$ \\
\hline Mean & 10.15 & 11.10 & 16.19 & 17.11 & 5.19 & 5.83 \\
\hline $\begin{array}{l}\text { Standard } \\
\text { deviation }\end{array}$ & 0.62 & 0.67 & 0.87 & 0.88 & 0.58 & 0.49 \\
\hline Minimum & 9.20 & 9,58 & 14.82 & 15.60 & 3.88 & 4,75 \\
\hline Maximum & 11.74 & 12.36 & 18.13 & 19.09 & 6.58 & 6.55 \\
\hline CV\% & 6.11 & 6.04 & 5.37 & 5.14 & 11.23 & 8.43 \\
\hline
\end{tabular}

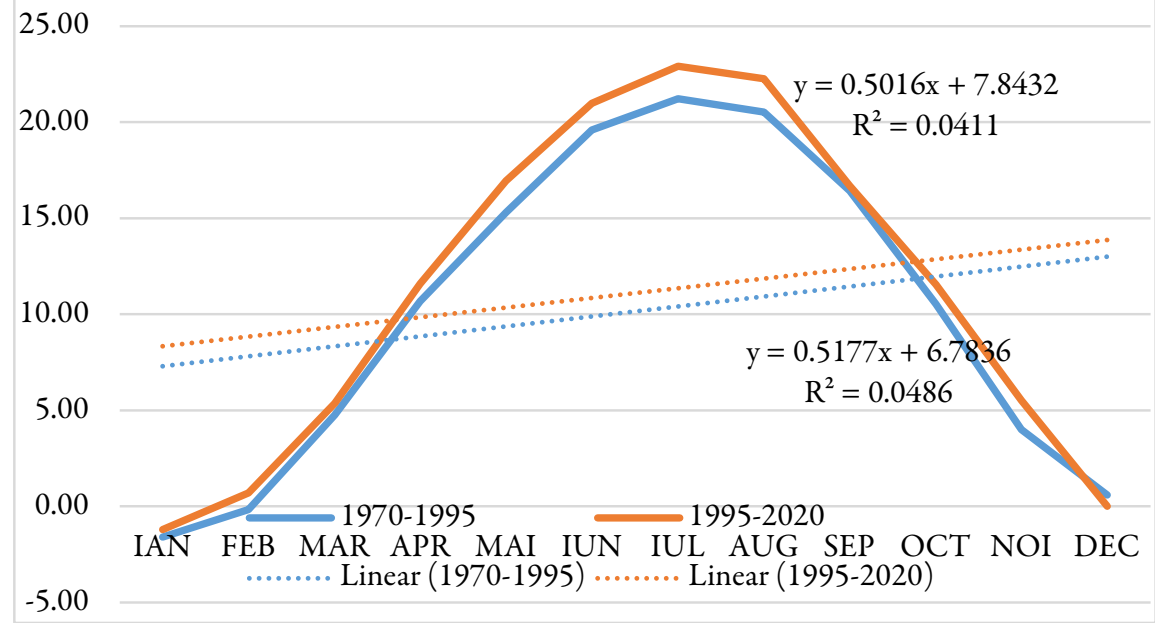

Figure 1. Evolution of monthly average temperatures over the analysed time intervals 
The increase of average daily air temperature generally leads to a reduction of the growing duration and earlier bud bursting. It is considered that, among the countless environmental factors that affect the development and implicitly the phenology of plant, temperature is probably the most important in the case of bud bursting, leafing and flowering in temperate climates (Tooke and Battey, 2010; Heide, 2011; Polgar and Primack, 2011).

According to the climatic data (Figure 1) there is a tendency to increase the average monthly temperature, following the model of a linear line whose equation is $y=0.5177 x+6.7836$ for the interval 1970 1995 and $y=0.5177 x+6.7836$, for the period 1995-2020. Over the analysed periods, the temperature increased continuously, the trend being linear and the confidence interval was $\pm 0.5^{\circ} \mathrm{C}$. This trend of increasing temperature is supported by many researchers (Della Marta et al., 2007; Cosmulescu et al., 2010 a, b; Cosmulescu et al., 2015; Cosmulescu and Gruia, 2016; Cosmulescu and Ionescu, 2018).

\section{Regarding the analysis of spring phenology by species, climatic year and area}

The time of phenological stages varies depending on species, on age and on the local climate within a species. In recent years, the difference between spring vegetation phenology between towns and surrounding areas has been used to quantify the effects of urbanization on spring vegetation phenology (Li et al., 2016; Zhou et al., 2016; Yao et al., 2017). In the present study the difference between spring phenology of urban vegetation, from two different areas, depending on the species of ornamental shrubs and depending on the climatic year are summarized in Table 3.

Table 3. The starting date of spring phenological phases depending on species of ornamental shrubs and climatic year [in days]

\begin{tabular}{|c|c|c|c|c|c|c|c|c|c|c|c|c|c|c|c|}
\hline \multirow{2}{*}{$\begin{array}{c}\text { Species/BBC } \\
\text { H Code }\end{array}$} & \multirow{2}{*}{ Year } & \multicolumn{2}{|c|}{09} & \multicolumn{2}{|c|}{19} & \multicolumn{2}{|c|}{39} & \multicolumn{2}{|c|}{59} & \multicolumn{2}{|c|}{60} & \multicolumn{2}{|c|}{65} & \multicolumn{2}{|c|}{69} \\
\hline & & $\mathrm{Z1}$ & $\mathrm{Z} 2$ & $\mathrm{Z1}$ & $\mathrm{Z} 2$ & $\mathrm{Z1}$ & $\mathrm{Z} 2$ & $\mathrm{Z1}$ & $\mathrm{Z} 2$ & $\mathrm{Z1}$ & $\mathrm{Z} 2$ & $\mathrm{Z1}$ & $\mathrm{Z} 2$ & $\mathrm{Z1}$ & $\mathrm{Z} 2$ \\
\hline \multirow{5}{*}{$\begin{array}{l}\text { Forsythia } \\
\text { intermedia }\end{array}$} & 2019 & 120 & 121 & 122 & 123 & 128 & 129 & 130 & 131 & 131 & 132 & 135 & 136 & 179 & 181 \\
\hline & 2020 & 126 & 127 & 106 & 108 & 108 & 110 & 109 & 111 & 111 & 112 & 118 & 119 & 150 & 152 \\
\hline & 2021 & 136 & 138 & 138 & 140 & 144 & 146 & 145 & 147 & 146 & 148 & 150 & 152 & 189 & 191 \\
\hline & Mean & 127.33 & 128.67 & 122 & 123.67 & 126.67 & 128.33 & 128 & 129 & 129.33 & 130.67 & 134.33 & 135.67 & 172.67 & 174.67 \\
\hline & SD & 8.08 & 8.62 & 16 & 16.01 & 18.03 & 18 & \begin{tabular}{|l|}
18.08 \\
\end{tabular} & 18.03 & 17.56 & 18.03 & 16.01 & 16.50 & 20.26 & 20.26 \\
\hline \multirow{5}{*}{$\begin{array}{l}\text { Mahonia } \\
\text { aquifolium }\end{array}$} & 2019 & 112 & 114 & 118 & 120 & 129 & 131 & 137 & 139 & 145 & 147 & 170 & 172 & 192 & 194 \\
\hline & 2020 & 103 & 105 & 117 & 119 & 121 & 123 & 124 & 125 & 129 & 130 & 150 & 154 & 187 & 189 \\
\hline & 2021 & 131 & 133 & 135 & 137 & 145 & 148 & 158 & 160 & 159 & 161 & 166 & 168 & 196 & 198 \\
\hline & Mean & 115.33 & 117.33 & 123.33 & 125.33 & 131.67 & 134 & 139.67 & 141.33 & 144.33 & 146 & 162 & 164.67 & 191.67 & 193.67 \\
\hline & SD & 14.29 & 14.29 & 10.16 & 10.16 & 12.22 & 12.77 & 17.16 & 17.62 & 15.01 & 15.52 & 10.58 & 9.45 & 4.51 & 4.51 \\
\hline \multirow{5}{*}{$\begin{array}{l}\text { Spiraea } \\
\text { vanhouttei }\end{array}$} & 2019 & 146 & 148 & 171 & 173 & 175 & 177 & 177 & 189 & 179 & 181 & 196 & 198 & 216 & 220 \\
\hline & 2020 & 132 & 134 & 135 & 137 & 140 & 142 & 153 & 155 & 167 & 169 & 172 & 174 & 217 & 219 \\
\hline & 2021 & 130 & 132 & 133 & 137 & 150 & 153 & 179 & 181 & 187 & 189 & 195 & 197 & 215 & 217 \\
\hline & Mean & 36 & 138 & 146.33 & 149 & 155 & 157.33 & 169.67 & 175 & 177.67 & 179.67 & 187.67 & 189.67 & 216 & 218.67 \\
\hline & SD & 72 & 8.72 & 21.39 & 20.78 & 18.03 & 17.90 & \begin{tabular}{|l|}
14.47 \\
\end{tabular} & 17.78 & 10.07 & 10.07 & 13.58 & 13.58 & 1.21 & 1.53 \\
\hline \multirow{5}{*}{$\begin{array}{l}\text { Syringa } \\
\text { vulgaris }\end{array}$} & 2019 & 146 & 148 & 155 & 157 & 171 & 173 & 172 & 175 & 173 & 176 & 175 & 178 & 201 & 203 \\
\hline & 2020 & 136 & 138 & 145 & 147 & 149 & 151 & 159 & 161 & 163 & 16 & 175 & 177 & 205 & 207 \\
\hline & 2021 & 140 & 142 & 141 & 143 & 144 & 146 & 171 & 172 & 185 & 187 & 189 & 191 & 226 & 228 \\
\hline & Mean & 140.67 & 142.67 & 147 & 149 & 154.67 & 156.67 & 167.33 & 169.33 & 173.67 & 176 & 179.67 & 182 & 210.67 & 212.67 \\
\hline & SD & 5.03 & 5.03 & 7.21 & 7.21 & 14.36 & 14.36 & 7.23 & 7.37 & 11.01 & 11 & 8.08 & 7.81 & 13.43 & 13.43 \\
\hline \multirow{5}{*}{$\begin{array}{l}\text { Albizia } \\
\text { julibrissin }\end{array}$} & 2019 & 182 & 184 & 192 & 195 & 206 & 209 & 227 & 229 & 233 & 235 & 244 & 246 & 307 & 309 \\
\hline & 2020 & 194 & 196 & 203 & 205 & 215 & 217 & 234 & 236 & 241 & 243 & 251 & 253 & 317 & 320 \\
\hline & 2021 & 196 & 199 & 198 & 199 & 208 & 210 & - & - & - & - & - & - & - & - \\
\hline & Mean & 190.67 & 193 & 197.67 & 199.67 & 209.67 & 212 & 230.5 & 232.5 & 237 & 239 & 247.5 & 249.5 & 312 & 314.5 \\
\hline & SD & 7.57 & 7.94 & 3.18 & 5.03 & 4.73 & 4.36 & 4.95 & 4.95 & 5.66 & 5.66 & 4.95 & 4.95 & 7.07 & 7.78 \\
\hline \multirow{5}{*}{$\begin{array}{l}\text { Chaenomeles } \\
\text { japonica }\end{array}$} & 2019 & 115 & 117 & 125 & 127 & 135 & 136 & 139 & 140 & 143 & 144 & 155 & 156 & 175 & 178 \\
\hline & 2020 & 117 & 118 & 118 & 119 & 122 & 123 & 123 & 124 & 125 & 126 & 207 & 208 & 230 & 231 \\
\hline & 2021 & 113 & 116 & 121 & 123 & 130 & 132 & 125 & 127 & 131 & 133 & 155 & 158 & - & - \\
\hline & Mean & 115 & 117 & 121.33 & 123 & 129 & 130.33 & 129 & 130.33 & 133 & 134.33 & 172.33 & 174 & 202.5 & 204.5 \\
\hline & SD & 2 & 1 & 3.51 & 4 & 6.56 & 6.66 & 8.72 & 8.50 & 9.17 & 9.07 & 30.02 & 29.46 & 38.89 & 37.47 \\
\hline
\end{tabular}


From the analysis of the results on the number of days from November 1 to the beginning of different spring phenophases, differences are found both depending on the analysed shrub species and depending on the area and climate. If in Forsytia intermedia species the bud bursting (09) occurred at 120 days after November 1 in 2019, at 126 days in 2020 and at 136 days in 2021 in the town center (Z1), in the neighbouring area (Z2) it occurred 1-2 days later, in all three years. In $M$. aquifolium, the difference between budding (09) in Z1 zone and Z2 was two days and the number of days from November 1 to bud bursting was different depending on the climatic year, being between 103 days (2020) and 131 days (2021) in the city center and between 105 (2020) and 133 (2021) in the neighbouring area Z2. In Spiraea vanhoutei, the difference from one year to another between the number of days from November 1 to budding (09) is between 2 and 16 days, and from one area to another is 2 days. In $S$. vulgaris the difference from one climatic zone to another is also 2 days and the difference from one climatic year to another is between 4 and 10 days. In A. julibrissin, the differences from one climatic zone to another, regarding the number of days from November 1 to bud bursting (09) were 1-3 days and from one climatic year to another between 2 and 14 days. Also, in $C$. japonica there were differences of 1-3 days from one climatic zone to another, and 2-4 days from one year to another. Badeck et al. (2004) consider that early budding and flowering in temperate zones are an effect of climate change associated with rising temperatures, and Tian et al. (2020) showed that spring phenology begins earlier in urban areas than in surrounding areas due to rising city temperatures. With regard to flowering (60), there were also differences between the number of days from November 1 at the beginning of this phenophase, both depending on climatic year and species but also depending on climatic zone. In 2019, the differences from one area to another were 1 day in $C$. japonica, F. intermedia, 2 days in $M$. aquifolium, $S$. vanhouttei and 3 days in $S$. vulgaris. In 2020, the differences from one area to another were 1 day in $F$. intermedia, $M$. aquifolium, $C$. japonica, 2 days in $S$. vanhouttei and $S$. vulgaris. In 2021 these differences were 2 days in all species of ornamental shrubs analyzed. The results obtained are in line with those stated by Parece and Campbell (2018), namely that microclimatic variations produce intra-urban differences in vegetation phenophases. The end of flowering (69) recorded differences from one area to another, differences that were between 2 days in F. intermedia, M. aquifolium and S. vulgaris and 4 days in $S$. vanhouttei, in 2019, between 1 day in $C$. japonica and 2 days for the other species of ornamental shrubs in 2020 and 2 days in 2021 for all species analyzed. It can be seen that, regardless of species and regardless of climatic year, the beginning of each spring phenophase occurs earlier in the urban area compared to the neighbouring area. Other studies too have showed differences between rural-urban phenology: on average 15 days (Li et al., 2016), 3.56 days (Gervais et al., 2017). Yang et al. (2020) showed that the beginning of vegetation season (SOS) in urban areas occurred 7.4 days earlier than in rural areas, the end of vegetation season (EOS) in urban areas occurred 5 days later than in rural areas, and in urban areas the phenology was also influenced by the type of vegetation and the different level of urbanization. It can also be seen that, regardless of climatic zone, bud bursting (09) begins at the earliest in $C$. japonica and $M$. aquifolium and at the latest in $S$. vulgaris and $S$. vanhouttei, the beginning of flowering (60) begins at earlier in F. intermedia and later in $S$. vanhouttei, and flowering ends (69) earlier in C. japonica in 2019 and later in A. julibrissin, regardless of climatic year. From the appearance of inflorescence (59) to the end of flowering (69), on average, a different number of days pass depending on the area (urban climate zone - neighbouring area): 44.67 - 45.67 days in $F$. intermedia, 52 - 53 days in $M$. aquifolium, 43.34 - 44 days in S. vulgaris, 46.33 - 43.67 days in $S$. vanhouttei, 73.50 - 74.17 days in $C$. japonica, which shows that the duration of flowering phenophase is shorter in the urban climate zone, compared to the neighbouring zone. The spring phenology of four ornamental trees was also analyzed, depending on the climatic year and the climatic zone, and the results obtained are presented in Table 4. It can be seen that there are differences from one species to another, from one climatic year to another, and also from one climatic zone to another. In 2019 the bud bursting (09) occurred earlier in the urban area by 1 day in $P$. cerasifera, by 2 days in A. hippocastanum and T. tomentosa and by 4 days in C. bignonioides, in 2020 it occurred earlier by 1 day in all species of ornamental trees analyzed, and in 2021 it occurred 2 days earlier in the urban area in all species analyzed except for $P$. cerasifera in which bud bursting occurred 3 days earlier. Flowering (60) registered an earlier onset in the urban area compared to the rural one and depending 
on the climatic year with 2-3 days earlier in A. hippocastanum, 1-3 days earlier in C. bignonioides, 1-2 days earlier in $P$. cerasifera and 2 days earlier in T. tomentosa. There are also differences in flowering (60) and from one climatic year to another, depending on the species: in A. hippocastanum differences between 6 and 17 days in Z1, and between 6 and 18 days in Z2; in T. tomentosa differences between 7 and 16 days; in C. bignonioides between 12-20 days in Z1, and between 11 and 21 days in Z2; in P. cerasifera differences of 5-6 days in Z1 and 6-7 days in $\mathrm{Z} 2$.

Table 4. The starting date of spring phenological phases depending on ornamental tree species and climatic year [in days]

\begin{tabular}{|c|c|c|c|c|c|c|c|c|c|c|c|c|c|c|c|}
\hline \multirow{2}{*}{$\begin{array}{l}\text { Species/BBCH } \\
\text { Code } \\
\end{array}$} & \multirow{2}{*}{ Year } & \multicolumn{2}{|c|}{09} & \multicolumn{2}{|c|}{19} & \multicolumn{2}{|c|}{39} & \multicolumn{2}{|c|}{59} & \multicolumn{2}{|c|}{60} & \multicolumn{2}{|c|}{65} & \multicolumn{2}{|c|}{69} \\
\hline & & $\mathrm{Z1}$ & $\mathrm{Z2}$ & $\mathrm{Z1}$ & $\mathrm{Z} 2$ & $\mathrm{Z1}$ & $\mathrm{Z} 2$ & $\mathrm{Z1}$ & $\mathrm{Z2}$ & $\mathrm{Z1}$ & $\mathrm{Z} 2$ & $\mathrm{Z1}$ & $\mathrm{Z} 2$ & $\mathrm{Z1}$ & $\mathrm{Z} 2$ \\
\hline \multirow{5}{*}{$\begin{array}{c}\text { Aesculus } \\
\text { hippocastanum }\end{array}$} & 2019 & 163 & 165 & 173 & 176 & 177 & 179 & 188 & 190 & 197 & 200 & 205 & 207 & 237 & 238 \\
\hline & 2020 & 146 & 147 & 149 & 151 & 156 & 158 & 172 & 174 & 180 & 182 & 188 & 190 & 214 & 216 \\
\hline & 2021 & 160 & 162 & 162 & 164 & 167 & 169 & 174 & 176 & 186 & 188 & 206 & 209 & 239 & 241 \\
\hline & Mean & 156,33 & 158 & 161,33 & 163,66 & 166,67 & 168,67 & 178 & 180 & 187 & 190 & 199,67 & 202 & 230 & 232,67 \\
\hline & SD & 9,07 & 9,64 & 12,01 & 12,50 & 10,50 & 10,50 & 8,72 & 8,71 & 8,62 & 9,17 & 10,12 & 10,44 & 13,89 & 13,65 \\
\hline \multirow{5}{*}{$\begin{array}{c}\text { Tillia } \\
\text { tomentosa }\end{array}$} & 2019 & 145 & 147 & 171 & 174 & 182 & 184 & 184 & 186 & 206 & 208 & 217 & 219 & 236 & 238 \\
\hline & 2020 & 141 & 143 & 177 & 179 & 186 & 188 & 192 & 193 & 213 & 215 & 220 & 222 & 243 & 245 \\
\hline & 2021 & 164 & 166 & 166 & 168 & 183 & 185 & 195 & 197 & 222 & 224 & 232 & 234 & - & - \\
\hline & Mean & 150 & 152 & 171,33 & 173,67 & 183,67 & 185,67 & 190,33 & 192 & 213,67 & 215,67 & 223 & 225 & 239,5 & 241,5 \\
\hline & SD & 12,29 & 12,29 & 5,50 & 5,50 & 2,08 & 2,08 & 5,68 & 5,57 & 8,02 & 8,02 & 7,93 & 7,94 & 4,95 & 4,95 \\
\hline \multirow{5}{*}{$\begin{array}{c}\text { Catalpa } \\
\text { bignonioides }\end{array}$} & 2019 & 171 & 175 & 179 & 182 & 196 & 200 & 209 & 212 & 227 & 230 & 229 & 231 & 244 & 246 \\
\hline & 2020 & 198 & 199 & 199 & 200 & 210 & 211 & 213 & 214 & 219 & 220 & 223 & 224 & 237 & 238 \\
\hline & 2021 & 176 & 178 & 185 & 187 & 182 & 184 & 183 & 185 & 207 & 209 & 211 & 214 & - & - \\
\hline & Mean & \begin{tabular}{|l|l|}
181,67 \\
\end{tabular} & 184 & 187,67 & 189,66 & 196 & 198,33 & 201,67 & 203,67 & 217,67 & 219,67 & 221 & 223 & 240,5 & 243 \\
\hline & SD & 14,36 & 13,07 & 10,26 & 9,29 & 14 & 13,58 & 16,29 & 16,20 & 10,07 & 10,50 & 9,17 & 8,54 & 4,95 & 5,66 \\
\hline \multirow{5}{*}{$\begin{array}{l}\text { Prunus } \\
\text { cerasifera }\end{array}$} & 2019 & 120 & 121 & 121 & 122 & 132 & 134 & 138 & 139 & 139 & 140 & 150 & 151 & 166 & 167 \\
\hline & 2020 & 115 & 116 & 120 & 121 & 131 & 133 & 139 & 141 & 144 & 146 & 151 & 155 & 161 & 164 \\
\hline & 2021 & 122 & 125 & 137 & 139 & 145 & 148 & 142 & 144 & 145 & 147 & 156 & 157 & - & - \\
\hline & Mean & 119 & 120.67 & 126 & 127.33 & 136 & 138.33 & 139.67 & 141.33 & 142.67 & 144.33 & 152.33 & 154.33 & 163.5 & 165.5 \\
\hline & SD & 3.61 & 4.51 & 9.54 & 10.12 & 7.81 & 8.39 & 2.08 & 2.52 & 3.21 & 3.79 & 3.21 & 3.05 & 3.54 & 2.12 \\
\hline
\end{tabular}

The number of days from November 1 at the end of flowering (69) differed from year to year by a maximum of 15 days in A. hippocastanum, by 7 days in C. bignonioides, by 7 days in T. tomentosa and by 5 days in $P$. cerasifera, but also from one climatic zone to another, starting 1-2 days earlier in the urban area in $A$. hippocastanum and C. bignonioides and with 1-3 days earlier in $P$. cerasifera. It can also be seen that, regardless of the climatic zone and the climatic year, spring phenophases begin at the earliest in $P$. cerasifera and at the latest in C. bignonioides, and from the appearance of the inflorescence (59) until the end of flowering (69) in average there are 52 days in A. hippocastanum, 49.17 days in T. tomentosa, 38.83 days in C. bignonioides and 23.83 days in $P$. cerasifera, in the urban climate zone and on average 52.67 days in A. hippocastanum, 49.50 days in T. tomentosa, 39.33 days in C. bignonioides and 24.17 days in P. cerasifera, in the neighbouring area. From bud bursting (09) to the end of flowering (69), the average flow is 73.67 days in A. hippocastanum, 89.5 in T. tomentosa, 58.83 days in C. bignonioides and 44.5 days in P. cerasifera, in the urban climate zone and on average 74.67 days in A. hippocastanum, 90 days in T. tomentosa, 59 days in C. bignonioides and 44.85 days in $P$. cerasifera, in the surrounding area. It is found that the number of days from bud bursting until the end of flowering is lower in the urban climate zone by at least 1 day compared to the neighbouring area.

\section{Conclusions}

The spring phenology of species of ornamental shrubs and trees is depending on the climatic year, in recording differences between the number of days from November 1 and the beginning of each spring phenophase, both from one species to another and from one climatic year to another, but also from one climatic zone to another, the spring phenology, starting earlier in the urban climate zone regardless of the species and 
the climatic year. Higher temperatures, rising from one year to another, are speeding-up the onset and development of spring phenology, regardless of species, and the urban climate through the effect of the island of urban heat leads to earlier onset of spring phenophases and shortening the growing season, so that due to phenological differences existing within the species from one climatic year to another and from one climatic zone to another, spring phenology can be considered an indicator of temperature increase.

\section{Authors' Contributions}

Conceptualization: SC; Investigation: ABS; Methodology: SC, ABS, MI; Writing - original draft: ABS, MI; Writing - review and editing: SC. All authors read and approved the final manuscript.

\section{Acknowledgements}

This research received no specific grant from any funding agency in the public, commercial, or not-forprofit sectors.

\section{Conflict of Interests}

The authors declare that there are no conflicts of interest related to this article.

\section{References}

Badeck FW, Bondeau A, Böttcher K, Doktor D, Lucht W, Schaber J, Sitch S (2004). Responses of spring phenology to climate change. New Phytologist 162(2):295-309. https://doi.org//10.1111/j.1469-8137.2004.01059.x

Buitenwerf R, Rose L, Higgins SI (2015). Three decades of multi-dimensional change in global leaf phenology. Nature Climate Change 5:364-368. https://doi.org/10.1038/nclimate2533

Cosmulescu S, Baciu A, Botu M, Achim G (2010a). Environmental factors' influence on walnut flowering. Acta Horticulturae 861:83-88.

Cosmulescu S, Baciu A, Cichi M, Gruia M (2010b). The effect of climate changes on phenological phases in plum tree (Prunus domestica) in south-western Romania. South-Western Journal of Horticulture, Biology and Environment 1(1):9-20.

Cosmulescu S, Baciu A, Gruia M (2015). Influence of climatic factors on the phenology spring in Southern Oltenia (Romania). Journal of Horticulture, Forestry and Biotechnology 19(1):147-158.

Cosmulescu S, Gruia M (2016). Climatic variability in Craiova (Romania) and its impacts on fruits orchards. Southwestern Journal of Horticulture, Biology and Environment 7(1):15-26.

Cosmulescu SN, Ionescu MB, Netoiu C (2019). Impact of climatic factors on radial growth in walnut (Juglans regia L.). Notulae Scientia Biologicae 11(2):304-308. https://doi.org/10.15835/nsb11210492

Cosmulescu S, Ionescu MB (2018). Phenological calendar in some walnut genotypes grown in Romania and its correlations with air temperature. International Journal of Biometeorology 62(11):2007-2013. https://doi.org/10.1007/s00484-018-1606-3

Cosmulescu S, Stanciu AB, Ionescu M (2020). The influence of temperature on phenology of ornamental woody species in urban environment. Scientific Papers-Series B, Horticulture 64(1):61-67.

Cosmulescu S, Scrieciu F (2019). Development of vegetation stages in medlar genotypes (Mespilus germanica L.) coded and described according to the BBCH scale. Biharean Biologist 14:116-119. 
Della Marta PM, Haylock MR, Luterbacher J, Wanner H (2007). Doubled length of western European summer heat waves since 1880. Journal of Geophysical Research: Atmospheres 112:D15. https://doi.org/10.1029/2007JD008510

Fitchett JM, Grab SW, Thompson DI (2015). Plant phenology and climate change: Progress in methodological approaches and application. Progress in Physical Geography 39(4):460-482. https://doi.org/10.1177/0309133315578940

Gervais N, Buyantuev A, Gao F (2017). Modeling the effects of the urban built-up environment on plant phenology using fused satellite data. Remote Sensing 9:99. https://doi.org/10.3390/rs9010099

Han Q, Wang T, Jiang Y, Fischer R, Li C (2018). Phenological variation decreased carbon uptake in European forests during 1999-2013. Forest Ecology and Management 427:45-51. https://doi.org/10.1016/j.foreco.2018.05.062

Heide OM (2011). Temperature rather than photoperiod controls growth cessation and dormancy in Sorbus species. Journal of Experimental Botany 62(15):5397-5404. https://doi.org/10.1093/jxb/err213

Keenan TF, Gray J, Friedl MA, Toomey M, Bohrer G, Hollinger DY, Munger JW, O’Keefe J, Schmid HP, Wing IS (2014). Net carbon uptake has increased through warming-induced changes in temperate forest phenology. Nature Climate Change 4:598-604. https://doi.org/10.1038/NCLIMATE2253

Li X, Zhou Y, Asrar GR, Mao J, Li X, Li W (2016). Response of vegetation phenology to urbanization in the conterminous United States. Global Change Biology 23:2818-2830. https://doi.org/10.1111/gcb.13562

Matei I, Pacurar I, Rosca S, Bilasco S, Sestras P, Rusu T, Jude ET, Tăut FD (2020). Land use favourability assessment based on soil characteristics and anthropic pollution. Case study Somesul Mic valley corridor, Romania. Agronomy 10(9):1245. https://doi.org/10.3390/agronomy10091245

Meng L, Mao J, Zhou Y, Richardson AD, Lee X, Thornton PE, Jia G (2020). Urban warming advances spring phenology but reduces the response of phenology to temperature in the conterminous United States. Proceedings of the National Academy of Sciences 117(8):4228-4233. https://doi.org/10.1073/pnas.1911117117

Menzel A, Sparks TH, Estrella N, Koch E, Aasa A, Ahas R, ... Zust ANA (2006). European phenological response to climate change matches the warming pattern. Global Change Biology 12:1969-1976. https://doi.org/10.1111/j.1365-2486.2006.01193.x

Parece TE, Campbell JB (2018). Intra-urban microclimate effects on phenology. Urban Science 2(1):26. https://doi.org/10.3390/urbansci2010026

Piao S, Cui M, Chen A, Wang X, Ciais P, Liu J Tang Y (2011). Altitude and temperature dependence of change in the spring vegetation green-up date from 1982 to 2006 in the Qinghai-Xizang Plateau. Agricultural and Forest Meteorology 151:1599-1608. https://doi.org/10.1016/j.agrformet.2011.06.016

Polgar CA, Primack RB (2011). Leaf-out phenology of temperate woody plants: from trees to ecosystems. New phytologist 191(4):926-941. https://doi.org/10.1111/j.1469-8137.2011.03803.x

Richardson AD, Andy Black T, Ciais P, Delbart N, Friedl MA, Gobron N, Hollinger DY, Kutsch WL, Longdoz B, Luyssaert $S$ (2010). Influence of spring and autumn phenological transitions on forest ecosystem productivity. Philosophical Transactions of the Royal Society B: Biological Sciences 365:3227-3246. https://doi.org/10.1098/rstb.2010.0102

Shen M, Cao R (2015). Temperature sensitivity as an explanation of the latitudinal pattern of green-up date trend in Northern Hemisphere vegetation during 1982-2008. International Journal of Climatology 35:3707-3712. https://doi.org/10.1002/joc.4227

Shen M, Piao S, Chen X, An S, Fu YH, Wang S, Cong N, Janssens IA (2016). Strong impacts of daily minimum temperature on the green-up date and summer greenness of the Tibetan Plateau. Global Change Biology 22:3057-3066. https://doi.org/10.1111/gcb.13301

Stratópoulos LMF, Zhang C, Duthweiler S, Häberle KH, Rötzer T, Xu C, Pauleit S (2019). Tree species from two contrasting habitats for use in harsh urban environments respond differently to extreme drought. International Journal of Biometeorology 63:197-208. https://doi.org/10.1007/s00484-018-1653-9

Tian J, Zhu X, Wu J, Shen M, Chen J (2020). Coarse-resolution satellite images overestimate urbanization effects on vegetation spring phenology. Remote Sensing 12(1):117. https://doi.org/10.3390/rs 12010117

Tooke F, Battey NH (2010). Temperate flowering phenology. Journal of Experimental Botany 61(11):2853-2862. https://doi.org/10.1093/jxb/erq165

Wohlfahr G, Tomelleri E, Hammerle A (2019). The urban imprint on plant phenology. Nature Ecology and Evolution 3(12):1668-1674. https://doi.org/10.1038/s41559-019-1017-9 
Yang J, Luo X, Jin C, Xiao X, Xia JC (2020). Spatiotemporal patterns of vegetation phenology along the urban-rural gradient in Coastal Dalian, China. Urban Forestry and Urban Greening 54:126784. https://doi.org/10.1016/j.ufug.2020.126784

Yao R, Wang L, Huang X, Guo X, Niu Z, Liu H (2017). Investigation of urbanization effects on land surface phenology in Northeast China during 2001-2015. Remote Sensing 9:1-17. https://doi.org/10.20944/preprints201701.0051.v1

Zhou D, Zhao S, Zhang L, Liu S (2016). Remotely sensed assessment of urbanization effects on vegetation phenology in China's 32 major cities. Remote Sensing of Environment 176:272-281. https://doi.org/10.1016/j.rse.2016.02.010

Zipper SC, Schatz J, Singh A, Kucharik CJ, Townsend PA, Loheide SPA (2016). Urban heat island impacts on plant phenology: Intra-urban variability and response to land cover. Environmental Research Letters 11:54023. https://doi.org/10.1088/1748-9326/11/5/054023/meta

OPEN ACCESS

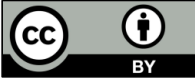

The journal offers free, immediate, and unrestricted access to peer-reviewed research and scholarly work. Users are allowed to read, download, copy, distribute, print, search, or link to the full texts of the articles, or use them for any other lawful purpose, without asking prior permission from the publisher or the author.

License - Articles published in Notulae Scientia Biologicae are Open-Access, distributed under the terms and conditions of the Creative Commons Attribution (CC BY 4.0) License.

(c) Articles by the authors; SHST, Cluj-Napoca, Romania. The journal allows the author(s) to hold the copyright/to retain publishing rights without restriction. 